\title{
Exploring the Relationship Between Different Technologically Improved Measures and Firm Performance: An Empirical Analysis Based on Manu- facturing in Shanghai 1998-2003
}

\author{
Xinmiao Zhou ${ }^{*}$, Jun Leng and Xinxin $\mathrm{Wu}$
}

Business School, Ningbo University, Ningbo, Zhejiang, 315211, China

\begin{abstract}
The paper analyses the effect of $R \& D$ and technology import on firm performance in Shanghai. We consider $R \& D$ and technology spill-over to be heterogeneous treatments, and using econometric matching, we account for possible selection bias. Our results suggest that, when compared to companies without any treatment, firms that receive either or both of our treatments yield positive effects. Technology import spill-over significantly influences the firm's profit and labor productivity, whereas R\&D is more important for improving the firm's Total Factor Productivity (TFP). It should be stressed that domestic companies in Shanghai should fully utilize the positive effects induced by the spillovers in technology trade to the joint companies and R\&D activities.
\end{abstract}

Keywords: Average treatment effect, econometric matching, firm performance, international technology spillovers, R\&D.

\section{INTRODUCTION}

During the past few decades, global exploring strategies for R\&D activities have significantly involved in industries and government. Considerable evidence suggests that the number of R\&D activities, mergers, technology imports, and alliances in various industries and the science have increased substantially. Advanced technology is crucial in economic development and growth. The technology gap between developed and developing country is not only a disadvantage for the latter, but this disparity also makes it difficult to catch up, so developing countries must take advantage of technological opportunities [1-4].

Since 1978, R\&D related measures and technology import spill-over are the two key factors of China's technological development. The recent year report of the OECD's Science, Technology and Industry Score board reports that China's technological development will definitely dramatically increase in the future, with R\&D spending growing 18 percent faster than its economy over the period 2000-2005, China's technology imports reached a record high in 2007. Referred to yearbook provided by the Ministry of Commerce, China has signed more than ten thousand technology import contracts since 2007, one of which was worth $\$ 22.02$ billion. The most important goal of Chinese government is to short the technological distance to the developed western countries. The domestic firm's ability to survive and to compete with their foreign counterparts has become a central concern for policy makers [5-7].

For the purposes of this paper, we have chosen the firm labor productivity, firm total factor productivity (TFP) and firm profit as the three indicators that measure overall performance, data collected from manufacturing in shanghai and given by firm-level specification. We explored the sources and kinds of differences between R\&D and technology import spill-over in economic sustainable development and profit growth among different companies with different characters.

The originality of our research can be illustrated in the following. Firstly, the econometric researches on China using firm-level samples are not often. Therefore, this study employed a specific dataset that contains firm-level detailed information and R\&D related information from several companies in Shanghai. We all know Shanghai is the most developed area in China even in Asia. Secondly, previous studies found if focused on ownership structures, the performance expresses differently; however, it was less clear which kind of ownership model was in place. Thirdly, as emphasized by Markusen and Venable (1999), Technology is playing more and more important role for healthy sustainable development to multinational enterprises. Innovation activities in developing countries usually start with learning by doing, and import some out of date technology from developed countries and then improve that. However, the phenomenon we mentioned has not obtained enough attention in past academic studies in China.

The issues we discussed here will be helpful to Chinese government and related section because the research is based on micro data base that make result is more fit the Chinese economic reality. By analyzing the treatment effects of different knowledge-based improvements made to technology import spill-over and $\mathrm{R} \& \mathrm{D}$ activities, we can investigate the possible benefits of these improvements, which is essential to the success of the Chinese government's long-term economic development plan. The major contribution of this paper is that distinguishes $\mathrm{R} \& \mathrm{D}$ activities and technology im- 
Table 1. Overview of manufacturing industrial firms in Shanghai (1998-2003).

\begin{tabular}{|c|c|c|c|c|c|}
\hline \multirow{2}{*}{ Points } & $\begin{array}{c}\text { Per Capita Industrial } \\
\text { Output in 1,000s }\end{array}$ & $\begin{array}{c}\text { Per Capita Labor Re- } \\
\text { muneration in 1,000s }\end{array}$ & $\begin{array}{c}\text { Technology Import } \\
\text { Intensity (in \%) }\end{array}$ & $\begin{array}{c}\text { R\&D Input } \\
\text { Intensity (in \%) }\end{array}$ & $\begin{array}{c}\text { Technical Personnel } \\
\text { Proportion (in \%) }\end{array}$ \\
\hline \hline \multirow{2}{*}{ SOEs } & 305.07 & 17.10 & 0.42 & 0.50 & $(0.13)$ \\
\hline \multirow{2}{*}{ JOINT } & $(87.33)$ & $(4.50)$ & $(0.29)$ & 0.89 & $(1.23)$ \\
\hline \multirow{2}{*}{$\begin{array}{c}\text { domestic non- } \\
\text { SOEs }\end{array}$} & $(172.74)$ & $(4.34)$ & 1.03 & $(0.12)$ & $(0.77)$ \\
\hline
\end{tabular}

Note: Standard deviation is given in brackets. Source: Statistical Yearbook of Shanghai Science and Technology.

port spill-over for individual research and simultaneously analyzes the correlation of these two strategies and their effects according to three different firm performance indicators.

The results suggest that the firms with different ownership prefer different technology development strategies, which impact the above three indicators. The advantages of technology spill-over have been embodied mainly in shortterm firm performances and from a long-term perspective, wherein R\&D played a key role. In addition, researchers have found that R\&D activities and technological spill-over have a strong positive mutual influence, so when the spillover effect is high, firms would produce positive R\&D response; in contrast, low spill-over situation would result in a reduction in R\&D expenditure [8-11].

This paper has been organized by 7 sections: Section 2 states the institutional context about technology improvement policies in China, and Section 3 summarizes the literatures in related area. Section 4 describes the economic assumptions and mathematical model used in this paper. Section 6 covers the econometric analysis results. In last Section, we present our conclusion.

\section{BACKGROUND INFORMATION ON SCIENCE AND TECHNOLOGY ACTIVITIES AND OWNER- SHIP STRUCTURE IN SHANGHAI}

There is a widespread belief that FDI is an important channel for, and source of, technology imports and R\&D activities in China. In the mid-and late 80's, the FDI moved gradually northward from Guangdong, Fujian to Shanghai. Until the late 90 's, Shanghai had been at the forefront of FDI absorption, secondly only to Guangdong, Fujian and Jiangsu. By the end of 2003, 32,061 FDI contracts, which amounted to $\$ 74.437$ billion, were signed. The actual FDI inflow was about $\$ 46.27$ billion, 9.26 per cent of their contractual value. From 1995 to 2001, with a fast GDP 27\% per year, the actual arrival amount of the advanced technology rose from $\$ 674$ million to $\$ 1.773$ billion. It then rocketed up to $\$ 11.795$ billion in 2002 and eventually reached $\$ 16.594$ billion, another 40 per cent, one year later.

We divided the large and medium-sized industrial enterprises in Shanghai into three categories, according to their business type and ownership structure. These enterprises consisted of SOEs, domestic companies (non-SOEs), and companies partially owned foreign capital also named joint ventures Table 1 presents the basic information about these enterprises between 1998 and 2003. We found that the per capita gross industrial output of the joint ventures was significantly higher than the domestic-funded enterprises, approximately twice the amount of the SOEs and 1.7 times that of the domestic non-SOEs. Such an obvious gap between domestic and foreign enterprises indicates that their production efficiency may also vary. The industrial output of the SOEs was lower than domestic non-SOEs; nevertheless, the domestic non-SOEs had the largest fluctuations. In addition, the per capita labor remuneration is roughly the same in domestic-funded enterprises, but it is significantly lower than the per capita labor remuneration of the joint ventures. Moreover, when compared to the domestic-funded enterprises, the R\&D input intensity of the joint ventures is about 0.39 percentage higher, whereas the SOEs and domestic nonSOEs in the R\&D input intensity were around the same. In terms of the technology import intensity, the lowest rate was the SOEs, with only 0.42 percent, while the joint ventures reach the highest rate, with 1.03 percent. Finally, there was not a significant difference between the proportion of technical personnel at each of the three types of enterprises. SOEs are had the highest amount of technical personnel, followed by joint ventures and domestic non-SOEs. In general, the macro-data suggests that the joint ventures and domestic enterprises differ significantly. In the following section, we will utilize the sample data of manufacturing industrial firms in Shanghai in order to further explain the effects of two technology development channels on the firm performance of those enterprises [12-14].

\section{LITERATURE REVIEW}

In recent decades, a number of scholars have extensively investigated R\&D activities and technology import spillover, as important impetuses of further economic growth. The present international discussion has largely concentrated on treating science and technology development as an asset for private firms, the government, universities, and other nonprofit organizations. It is necessary to identify the relationships between R\&D and the total effect of technology import spill-over on firm performance, which reflects both $R \& D$ returns and spillovers.

\subsection{R\&D Returns}

R\&D's effect on the economy can be examined at many various manners of aggregation, the returns has been re- 
searched very often spanned from individual to a national economy, or even global returns. Our study concentrates on private (firm-level) $R \& D$ returns.

Generally speaking, $R \& D$ returns have been estimated (Griliches (1980)) by comparing the productivity growth or profitability in different firms with the research expenditures, or the growth of the research stock, within these firms. Lichtenberg and Siegel (1991) report estimated R\&D returns, which are based on the productivity data for U.S. firms. Their estimation was taken from a large sample of firms, which greatly improved estimates of firm productivity. Nadiri (1993) summarizes related studies that concerned $\mathrm{R} \& \mathrm{D}$ returns within the data for individual firms.

Mansfield et al. (1971) and Scherer (1999) identified that R\&D plans might take certain technical and commercial risks and may be unsuccessful. Observed benefits to R\&D might partially convey a essential risk premium.

Nelson (1988) considers that R\&D and technological activities are almost intertwined. Firms with high R\&D normally will meet more development space and vice versa. Consequently, it is difficult to determine the extent to which the effects attributed to R\&D expenditures actually reflect the collateral technological opportunities. Therefore, Nelson argues that standard regressions, across firms or industries, cannot provide plausible estimates of the effect of R\&D investments. Olley and Pakes (1996) propose an important method that emphasizes simultaneity. Acharya and Keller (2007) use the thought of O-P to R\&D studies. These studies give abundant information about estimation to the return derived from R\&D activities. These researches give powerful evidence proved $R \& D$ is affected by some economic variables. Numerous economists start to find these key factors and expand economic analysis method such as instrumental methods (Lewbel, 1997), DiD methods with introduction of elasticity (Fung, 2004).

\subsection{Technology Import Spillovers}

In highly advanced economics, foreign technology spillovers play an important role in technical progress, whereas in smaller and less technically progressive countries, the economy is far more dependent on foreign technology spillover.

There are many academic researches discussed the situation about technology transference from developed countries to developing countries. They proposed the major channels such as international trade (Coe and Helpman, 1995) and FDI (Aitken and Harrison, 1999). In fact, the majority of the literature analyzes the effect of technology spill-over on domestic production from multinational companies. Undoubtedly, multinational companies significantly contribute to a country's economy, since their productivity is much higher than that of the domestic firms.

Coe and Helpman (1995) emphasize the effects of international trade to technological spill love. They point out imports could help poor technological country to reduce the gap with the wealthy countries. Pottelsberge de la Potterie (1998) raise a useful method to measure spill-overs among different countries.
But in recent research work, academicians start to focus on the qualities on samples for their study. Specific database is preferred to be used to analysis on firm performance. The results were testified more useful than the macro-data only used (Hallak and Levinsohn's 2004).

\subsection{Related Empirical Studies in China}

Using a Granger causality test, most of the Chinese studies analyze the impact of technology development strategies from a macro perspective. Chen (2001) examines the relationship between technology import and industrial technological progress and concludes that technology import stimulates technological development positively; however, it is not stable in the long-term. Bao and Lai (2002) assess the correlation among TFP, capital output ratio, and FDI. They concluded that FDI significantly influences TFP and the capital output ratio, while the impact of technology spill-over is less obvious. With regard to the "solow residual" theory, $\mathrm{Hu}$ (2003) tested the technical contribution from FDI to China's empirical economic growth, and he denied an existing positive relationship.

There are a few of the previous researches that tested the impact of R\&D activities on firm performance focused on the internal R\&D activities, while the rest of the research emphasized the scientific and technological investments from FDI. Undoubtedly, FDI plays an important role in R\&D activities and technology import; however, combining the impacts of R\&D and technology import spill-over when determining economic growth has led to some biased conclusions. Importantly, FDI includes both capital and technology. If researchers only include the total FDI figure into a model, then it is not easy to estimate the effect of the technical components of FDI to determine economic growth, which our study seeks to address.

Moreover, prior Chinese studies on R\&D and technology import spill-over generally adopted the classic OLS or discrete choice model, wherein only a few of them deal with technological development strategies as economic policy instruments. In fact, later research indicates that the treatment evaluation approach is better for measuring the impact of economic policies and interventions, which is why it has become increasingly popular recently (Becker and Ichino, 2002). Therefore, in our paper, we utilize matching method for the ATE in order to obtain the most precise results possible.

\section{RESEARCH DESIGN AND ECONOMETRICS METHODOLOGY}

Previous studies have suggested that R\&D and technology import spill-over could benefit the firms in various ways. If such strategies do prove to be effective in improving firms' performances, then the firms that actively participate in science and technology networks should display higher rates of innovation productivity, which would consequently result in increased rates of profitability, TFP, and labor productivity. The above mentioned three indictors can be used as a comprehensive performance measure of the firms' output ((Mahmut Yasar et al. 2007). Therefore, our results could also be explained in terms of firm performance. In the 
rest part, firm profit, firm TFP and firm labor productivity are used to present firm performance output synonymously.

We investigated the various firm characteristics by the probabilities. The whole sample companies have been divided into three groups: (i) firms that do not import technology, but perform R\&D activities; (ii) firms that import technology, but do not perform R\&D activities; and (iii) firms that participate in both $R \& D$ activities and technology imports.

We consider the R\&D activities and the engagement in technology imports as different "treatments" in order to distinguish the effects that can be attributed to $R \& D$ and/or to spill-over.

In this paper, we use matching estimators for the average treatment effects to calculate the results. As we know, the data of many economic studies are from nonrandomized. The estimation results may be biased when estimating the effects of the treatment, namely R\&D activities and technology in our study. Rosenbaum and Rubin (1983) proposed the method of propensity score matching method to reduce biased estimations, the estimation bias can be better eliminated when researchers compare results with different treated and control subjects.

Since our database only consists of 200 cross-section firms during the period of 1998-2003, adopting this method entails that the maximum number of data that we can use for analysis is just 200. Restricting the sample will apparently influence the quality of the estimation and therefore we chose not to use this estimator. To apply IV variables, we need to find useful instruments. However, it was quite tough job to obtain appropriate variable to use as requirement in our sample. In our case, the most suitable choice is the matching estimator, because there is no need for us to assume the formula of the equilibrium solutions. However, the inherent limitation is that the matching estimator still controls the finding heterogeneity between groups treated and controlled groups. In the following section, we will further prove the ideas we mentioned.

The PS method is easy to understand to consider a conditional probability of impacting a treatment given nontreatment samples,

$$
p(X) \equiv \operatorname{Pr}(D=1 \mid X)=E(D \mid X)
$$

In $\mathrm{E}(1), \mathrm{D}=\{0,1\}$ is the sample of accept treatment and $X$ is the multi vector of influential variables. If the samples that accept treatment is defined by $X$, we could get the similar characters for $p(x)$. Moreover, we still need give a statement for $\mathrm{i}$, the propensity score $p\left(X_{i}\right)$ is observed by individual company $\mathrm{i}$, It is very easy to calculate the ATT:

$$
\begin{aligned}
& \tau \equiv E\left(Y_{1 i}-Y_{0 i} \mid D_{i}=1\right) \\
& =E\left[E\left\{Y_{1 i}-Y_{0 i} \mid D_{i}=1, p\left(X_{i}\right)\right\}\right] \\
& =E\left[E\left\{Y_{1 i} \mid D_{i}=1, p\left(X_{i}\right)\right\}-E\left\{Y_{0 i} \mid D_{i}=0, p\left(X_{i}\right)\right\} \mid D_{i}=1\right]
\end{aligned}
$$

The most important factor is $Y_{1 i}$ and $Y_{0 i}$ given by a condition of $\left(p\left(X_{i}\right) \mid D_{i}=1\right)$, they are contrary aspects for two firms they have other identical characters.
Formally, one must utilize the conditional independence assumption after balancing the pretreatment variables, given the propensity score that states that the conditional of $\mathrm{p}(\mathrm{x})$ and the outcomes of the independent treatment are written as,

$$
D \perp X\left|p(X) \quad Y_{1} Y_{0} \perp D\right| X \quad Y_{1} Y_{0} \perp D \mid p(X)
$$

We will try to satisfy the balance hypotheses, then observations with the same propensity scores they possibly have the same probability distribution of different groups with different treatment situations. In our case, the different treatment states include following different $Y_{1 i}$ "values", only doing $\mathrm{R} \& \mathrm{D}$ work, only accepting technology spill-over, and doing both R\&D work and accepting technology spillover. Change to another thought, PS marks is known, exposure to treatment is random, this model will give us similar estimators for treated and controlled. A lot of popular models could estimate the propensity score. For instance, one could use $\operatorname{Pr}\left(D_{i} \mid X_{i}\right)=F\left\{h\left(X_{i}\right)\right\}$, here $\mathrm{F}($.$) is the normal or the lo-$ gistic cumulative distribution and $\mathrm{h}\left(\mathrm{X}_{\mathrm{i}}\right)$ is a function of the covariates with linear and higher terms.

$\mathrm{H}(\mathrm{x})$ could be correctly obtained to satisfy the assumptions of equilibrium balance situation. The good points are the PS scores will improve the results for equilibrium conditions. Higher scores, higher confidential areas are.

In this paper, we use the STATA package "pscore.ado" to estimate the propensity score, then test the balance hypotheses based on a specified algorithm. The technology may be limited another model restriction as common support, which means researchers only need to test the balancing property on the samples wherein the PS scores followed by different sample groups. Repeat to consider this common support during our simulation process that could help produce better estimations results.

Actually we cannot make same PS scores to treatment groups and control groups. We only can get the close results for these two groups. Of course there are many methods could help us to solve this problem. It is clear to refer the Journal of STATA, which has plentiful literatures discussed this problem.

In our study, we chose the Stratification Matching method, which divides the propensity scores according to different value ranges. It also could be easily processed by software procedure STATA. Input related parameters and set the assumptions given a required significance, PS scores and the coefficients for variables could be observed.

\section{DATA SOURCES, VARIABLES AND DESCRIP- TIVE STATISTICS}

\subsection{Data Sources}

Our samples are mainly comes from two ways: Shanghai Statistical Bureau and the yearbook offered by the Science and Technology Information Centre in Shanghai. After eliminating missing data and outliers, our sample includes 1,194 total sources of data. These sample firms account for about 10 to 15 percent of all of the industries that contributed to R\&D activities and imported technology in Shanghai during the period between 1998 and 2003. 
Table 2. Basic statistics of the related indictors (According to the type of enterprise registration).

\begin{tabular}{|c|c|c|c|c|c|c|}
\hline & \multicolumn{2}{|c|}{ SOEs } & \multicolumn{2}{c|}{ Domestic non-SOEs } & \multicolumn{2}{c|}{ JOINT } \\
\hline & Mean & Stand dev. & Mean & Stand dev. & Mean & Stand dev. \\
\hline \hline Per capita Turnover in 1,000s & 145.15 & 137.10 & 209.62 & 175.53 & 616.31 & 761.79 \\
\hline Per capita increase in 1,000s & 0.45 & 0.71 & 0.52 & 0.82 & 1.90 & 3.27 \\
\hline Per capita fixed asset in 1,000s & 132.78 & 98.33 & 157.98 & 138.73 & 415.64 & 583.66 \\
\hline Per capita R\&D input in 1,000s & 0.99 & 2.82 & 0.99 & 2.59 & 4.40 & 16.93 \\
\hline Per capita technology import expenditure in 1,000s & 0.49 & 4.42 & 0.34 & 1.81 & 5.85 & 36.80 \\
\hline S\&T personnel proportion (in \%) & 0.08 & 0.10 & 0.06 & 0.11 & 0.05 & 0.10 \\
\hline Employees & 767 & 149 & 1078 & 128 & 890 & 109 \\
\hline
\end{tabular}

Since the production processes, resource utilization, and developing paths of each of the firm samples vary significantly, this paper will employ the industrial classification data, rather than the mixed data. With reference to the United Nations International Standard Industrial Classification (ISIC), we divided the whole sample into seven major industries, including those that are related to: clothing and food; chemical products and pharmaceuticals; non-metallic mineral products and metal manufacturing; general and special manufacturing; electrical machinery manufacturing; communications, computers, and other electronic equipment manufacturing; and other industries. In addition, according to the different type of ownership structure, we divided our sample firms into joint ventures, SOEs, and domestic nonSOEs.

Table 2 presents the basic information of the related indicators.

From Table 2, we found that the advantages of Joint ventures are reflected in the per capita turnover, per capita increase, per capita fixed asset, per capita R\&D input, and per capita technology import expenditures. SOEs participate in more S\&T works and domestic non-SOEs have more employees, when compared to the other two groups.

\subsection{Variables and Descriptive Statistics}

In this study, we are trying to find out the extent to which companies' R\&D activities and technology spillovers affect their performances. We chose three variables, including the firm's profit, the firm's labor productivity, and the firm's TFP, in order to estimate the given firm's performance.

The value of the firm's profit comes directly from our database provided by the Shanghai statistics Bureau and the Science and Technology Information Centre in Shanghai. The firm's labor productivity and TFP are calculated in the first step with reference to the related economic theories.

Labor productivity has always been used as a key indicator of a given firm's performance. It not only measures the profitability of a firm, but it also reflects its cost minimizing ability and competitiveness (Grupp and Maital, 2001).

Our analysis depends on a Cobb-Douglas production function: labor factor and capital factor, represented in the following equation:
$Y_{i t}=A_{t} L_{i t}^{\alpha} K_{i t}^{\beta}, \alpha+\beta=1$

where $\mathrm{Y}_{\text {it }}$ is the value increase, $\mathrm{L}_{\mathrm{it}}$ and $\mathrm{K}_{\mathrm{it}}$ represent the labor factor (indicated by numbers of employees), and capital factor respectively, $\mathrm{A}_{\mathrm{t}}$ is the technological progress and $\alpha$ and $\beta$ are the elasticities parameters for labor and capital separately.

Under the hypothesis of constant returns to scale $(\alpha+\beta=1)$, the labor productivity equation can be written as:

$y_{i t}=A_{t} k_{i t}^{\beta}$

where $y_{i t}=\left(Y / L_{i t}\right)$ and $k_{i t}=(K / L)_{i t}$ are derivative expressions for corresponding equations.

TFP is indicator to present the level of technology improvement or the level of sustainable development. TFP is more and more important in recent three decades. In regards to developing countries, such as China, TFP is significant with output and labor force. Following the pioneering work of Solow (1956), we calculated the TFP using the traditional calculation function. It can be illustrated as the following:

$T F P=\frac{Y}{L^{\alpha} M^{\beta} K^{\gamma}}, \alpha+\beta+\gamma=1$

Taking the logarithm of equation 6 :

$\ln T F P_{i j t}=\ln Y_{i j t}-\alpha_{j} \ln L_{i j t}-\beta_{j} \ln M_{i j t}-\gamma_{j} \ln K_{i j t}, \alpha_{j}+\beta_{j}+\gamma_{j}=1(7)$

where $\mathrm{Y}$ is the output of sample company produced; $\mathrm{K}$ is the fixed capital we observed; $\mathrm{M}$ is the intermediate input; $\mathrm{L}$ is the labor input; $\mathrm{t}$ is the time; $\mathrm{j}$ is the industrial classification; i means firm i; and $\alpha_{j}, \beta_{j}$, and $\gamma_{j}$ are the output elasticities with respect to labor, intermediate input, and capital. They are different values among different firms. To get a more stable estimation, we assumed that $\alpha, \beta, \gamma$ are the same in identical industries. They are the average taken from the elasticities of the sample firms in particular industries. After we got $\alpha_{j}, \beta_{j}$, and $\gamma_{j}$, we could then calculate the lnTFP.

After we decided the indicators of the firm's performance, the other part of our study included testing whether the firms' performance is stimulated by $R \& D$ and/or technology 
Table 3. Descriptive statistics of the sample.

\begin{tabular}{|c|c|c|c|c|c|}
\hline Firm profit in $1,000 \mathrm{~s}$ & PROFIT & 66339 & 534772 & -334780 & 7341710 \\
\hline Log of Firm Total Factor Productivity & LNTFP & 0.329 & 0.645 & -4.473 & 3.096 \\
\hline Patent application & PAT & 0.147 & 0.354 & 0 & 1 \\
\hline New products export & NPE & 0.191 & 0.393 & 0 & 1 \\
\hline Technology development tax deduction & TDTU & 0.039 & 0.195 & 0 & 1 \\
\hline Joint venture & JOINT & 0.577 & 0.494 & 0 & 1 \\
\hline SOE & SOE & 0.223 & 0.417 & 0 & 1 \\
\hline Number of Obs. & \multicolumn{5}{|c|}{1194} \\
\hline
\end{tabular}

Note: The 6 industry dummies (INDUSTRY) are not listed.

import spill-over. The treatments are represented by three dummy variables: $R \& D$ indicates that the firms that are engaged in R\&D projects and TECHIMP denotes that the firms utilized international technology trade during the observable years. BOTH means that the firms use these two strategies at the same time. In our sample, the share of firms performing R\&D activities is about $56.9 \%$, while the firms that use international technology trade account for $15.9 \%$. Around $15 \%$ of the sample firms utilize both of these strategies, whereas $42 \%$ of the firms did not adopt any technological measures at all.

We used other variables as control varibles; for instance, Firm sizes are measured by the log value for the number of employees (LNEMP). We chose the dummy variable S\&T to reflect whether the firm has a particular S\&T department. Dummy PAT measures indicate whether the corresponding firm had at least one patent application during the period. The two other dummies, NPE and TDTU, represented whether the firm had new product exportation and whether it had been offered technology development tax deduction. The differences among the business sectors are represent by the term INDUSTRY. Additionally, in order to assess the influence of ownership structures, the whole sample has been divided into SOEs, non-SOEs, and Joint ventures.

The variables PAT, LNEMP, and S\&T are considered to be important because they reflect the Chinese government's aim of deducting the technology difference and enhancing competitiveness. In other words, in order to get more technology development tax deductions or receive more public funding, firms need to show more R\&D activities and also prove that they have the capacity and capability of carrying out their proposed research projects successfully. We use firm size to represent the capacity and variable LNEMP to reflect capabilities. These variables are important in measuring both R\&D activities and TECHIMP (Table 3 ).

In our study, the variations among the firms are not only represented by industry differences, but also controlled by ownership structures. Compared with Joint ventures, SOEs are more likely to carry out $R \& D$ activities, but they receive fewer spillovers from import technology. All of the dummies used are intended to ensure that the conditional independence assumption can be fulfilled. If endogeneity occurred, the actual treatment effect on the treated group can be underestimated, which would consequently weaken the productive power of our model. However, when the effect is positive, this problem is negligible.

\section{ESTIMATION RESULTS}

In this paper, we first estimated logit models on the variables R\&D, TECHIMP, and BOTH. We obtained the PS scores (the predicted probabilities) that give the matching parameters. The regression yielded comparable results for the three dependent variables (see Table 4).

The result shows that most of the variables chosen for the model have a significant impact on the treatment factors. The positive or negative effects of coefficients are roughly consistent with our expectations. Focusing on the different treatments of different types of firms we can see that the results differ significantly. The sign of the coefficient of SOE and JOINT contrasted with each other for the same treatment of either the R\&D or TECHIMP. This fact indicates that SOEs prefer R\&D activities, while Joint ventures welcome TECHIMP more. When the firms received both treatments, the indicated results are roughly the same as the 
Table 4. Logistic regression results.

\begin{tabular}{|c|c|c|c|c|c|c|}
\hline Variables & \multicolumn{2}{|c|}{ R\&D } & \multicolumn{2}{|c|}{ ТЕСНIMP } & \multicolumn{2}{|c|}{ ВОТН } \\
\hline LNEMP & $0.31^{* * *}$ & 0.09 & $0.21 * *$ & 0.09 & $0.24 * * *$ & 0.09 \\
\hline PAT & $2.17 * * *$ & 0.42 & 0.19 & 0.23 & $0.45^{*}$ & 0.23 \\
\hline TDTU & $2.53^{* *}$ & 1.08 & 0.39 & 0.36 & 0.46 & 0.37 \\
\hline JOINT & $-0.88 * * *$ & 0.22 & $0.57 * *$ & 0.24 & 0.23 & 0.24 \\
\hline SOE & $0.89 * * *$ & 0.26 & $-0.62 * *$ & 0.30 & $-0.55^{*}$ & 0.30 \\
\hline RHO & $2.51^{* * *}$ & 0.42 & $2.49^{* * *}$ & 0.40 & -- & -- \\
\hline Pseudo $\mathrm{R}^{2}$ & \multicolumn{2}{|c|}{0.45} & \multicolumn{2}{|c|}{0.29} & \multicolumn{2}{|c|}{0.24} \\
\hline Log likelihood & \multicolumn{2}{|c|}{-448.12} & \multicolumn{2}{|c|}{-371.51} & \multicolumn{2}{|c|}{-388.21} \\
\hline Number of Obs. & \multicolumn{6}{|c|}{1194} \\
\hline
\end{tabular}

Note: $* * *(* *, *)$ presents significance level of $1 \%, 5 \%$ and $10 \%$. Industrial dummies are not listed.

Table 5. The lost observations of common support restriction.

\begin{tabular}{|c|c|c|c|c|}
\hline \multirow{2}{*}{ Variables } & \multicolumn{2}{|c|}{ Initial Sample } & \multirow{2}{*}{$\begin{array}{c}\text { Lost Due to Common } \\
\text { Support Restriction }\end{array}$} & Lost Percent \\
\cline { 2 - 5 } & Treated & 679 & 497 & 18 \\
\hline \hline R\&D firms & 190 & 652 & 352 & 1.51 \\
\hline $\begin{array}{c}\text { Firms that participate in R\&D and also } \\
\text { import technology }\end{array}$ & 182 & 1001 & 0.92 \\
\hline
\end{tabular}

Note: same with table 4 .

firms that received either of the single treatments. The only difference is that in this case, the coefficient is insignificant for the joint ventures with 10 percent level significance and for the SOEs. This can be explained by the fact that it is unlikely for the firms with different ownership structures to adopt both of these measures simultaneously.

The correlation coefficient (RHO) between the R\&D and technology spill-over is positive significant because these two activities are linked to each other. This reflects the importance of technology spillovers as an efficient tool for determining R\&D incentives.

Creating common support is a necessary condition to ensure that the matching estimator is consistent; however, as stated above, the samples are often restricted to only common support in practice. If there is no overlap of propensity scores among the groups, or if the overlap is too small, then the matching estimator is not applicable. Table $\mathbf{5}$ give the impact of the common support restriction on each of the groups considered in the following matching analysis. The lost observations are about $1.51 \%, 29.48 \%$, and $0.92 \%$ in the case of R\&D, TECHIMP, and BOTH, respectively. The amount of lost observations is highest in the second situation because these firms are small, they have no technology imports. Therefore, we assume that the results are not significantly affected by the common support requirement. Fig. (1) presents the histograms of the propensity scores. The upper histograms display the distribution of the treated group and the lower part is the untreated group.

We chose to evaluate the Stratification Matching for each firm. Table 6 describes the estimation of ATT based on the propensity score. Compared with firms that receive no treatment, R\&D and technology spill-over were found to exhibit significant positive effects on the firms' performance. When the dependent variable is PROFIT and LBPRO, we find that TECHIMP presents better effects in treatment. We found that the firms that receive TECHIMP treatment outperform the firms that carry out R\&D. Meanwhile, we cannot deny the fact that technology import spill-over does contribute much more than R\&D on a firm's profit. However, for the firms that engaged in both of the development strategies, 


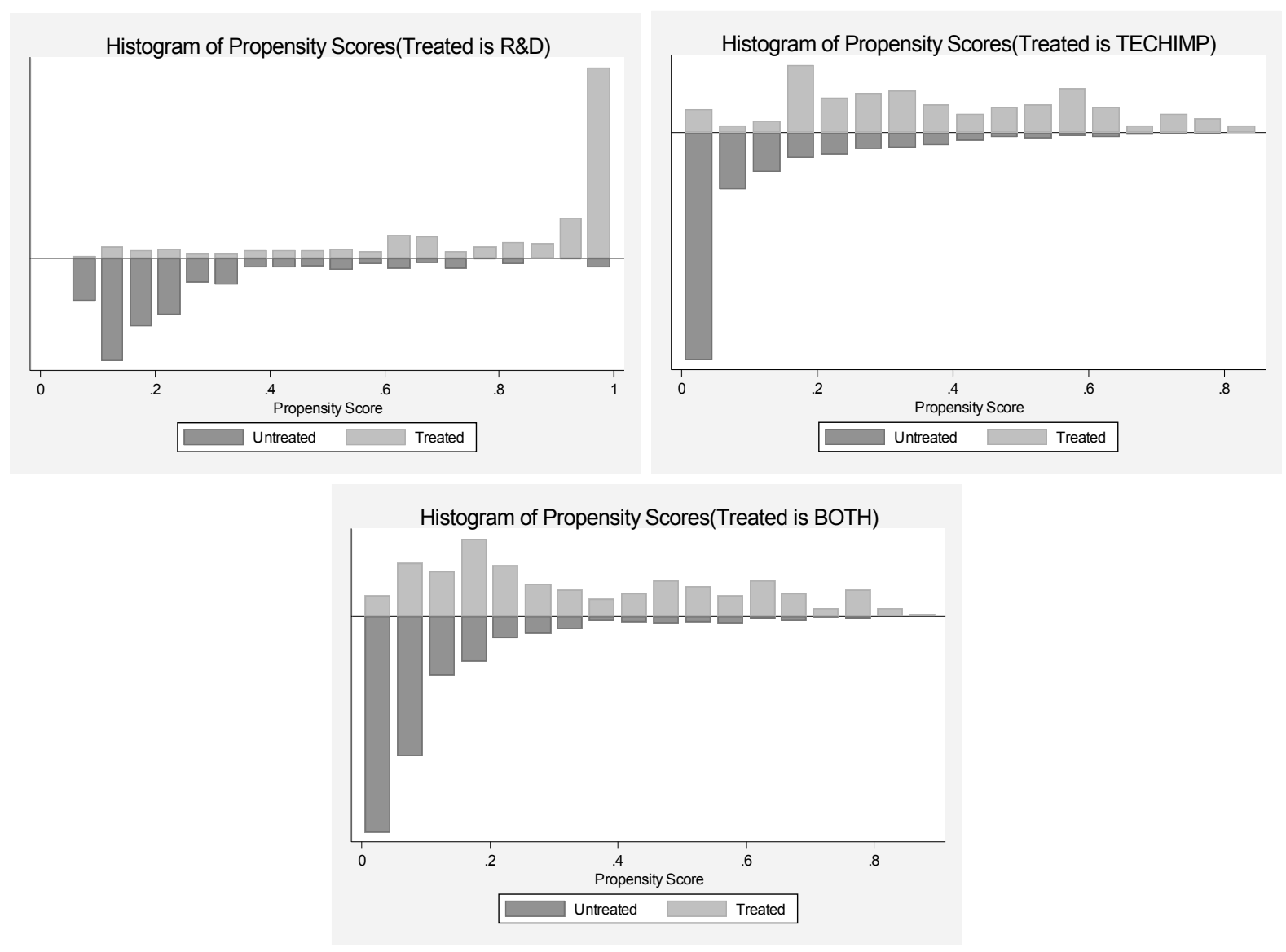

Fig. (1). Histograms of propensity scores.

no positive effect had been identified. When the dependent variable is LNTFP, then the result is the opposite of the above findings. Firms that are currently engaged in R\&D activities improve the firm TFP significantly, while technology import contributes the least to this indicator.

For the different dependent variables, the contribution of the two strategies varies considerably. Meanwhile, the three indictors that we choose to measure a firm's performance also have different meanings. In the short term, a firm's profit directly reflects the current period of the firm's performance and it is also the key measurement that particularly concerns employers. Our study confirms the positive effect of technology imports on firm performance. Nevertheless, this conclusion cannot be separated from the fact that FDI remains the biggest technology import carrier in China. Several studies have shown that FDI improves the profitability of the firms.

Firm labor productivity measures the labor efficiency during the production process and it is a combined indictor of a firm's technology, operations and management, staff proficiency and enthusiasm level. It reflects the long-term operating performance of the firm. Our study shows that, despite the fact that the effects of technology spill-over are still higher than the effects of R\&D, technology spill-over's comparative advantage is less obvious when the dependent variable is PROFIT. TFP measures the technological progress and it guarantees the long-term sustainable development of the firm. Advanced technology helps the firms to maintain their competitive strength and grow continuously. Our study confirmed the positive contribution of R\&D on TFP. Therefore, from a long-term perspective, increasing R\&D inputs will benefit the firm in future. Relying on FDI to enhance a firm's performance has proven to be effective in the short-run; however, higher R\&D investments secure the success of the firm in the long-term.

Again, economic theory has no clear prediction for the correlation effects. Considering the results of Tables $\mathbf{4}$ and $\mathbf{6}$ together, we find that if the spill-over effect is low, then firms reduce $R \& D$ investments, whereas a sufficiently high spill-over effect would encourage firms to increase the amount of R\&D expenditure. However, from the coefficient of BOTH we could tell the firms engaged in both of the development strategies simultaneously actually is not the best choice.

\section{CONCLUSION}

Given the high speed and rapid growth in recent 3 decades in China, it is significant to observe how science and technology activities affect the national economics of China. This study focused on the impact of firm performance and R\&D and international technology spillovers in China. In particular, we investigated whether R\&D and technology spill-over could have a positive impact on the firm's performance. In our study, the performance of the firm is measured by the firm's profit, the firm's labor productivity, and the firm's TFP. 
Table 6. ATT estimation on labor productivity and TFP with stratification matching method.

\begin{tabular}{|c|c|c|c|c|}
\hline \multicolumn{5}{|c|}{ THE TREATMENT IS R\&D } \\
\hline 679 & 497 & 21491.619 & 32115.6 & 0.669 \\
\hline \multicolumn{5}{|c|}{ The treatment is TECHIMP } \\
\hline 187 & 655 & 211000 & 54842.37 & 3.842 \\
\hline \multicolumn{5}{|c|}{ The treatment is BOTH } \\
\hline n. treat & n. contr. & ATT & Std. Err. & $\mathrm{T}$ \\
\hline n. treat & n. contr. & ATT & Std. Err. & $\mathrm{T}$ \\
\hline 679 & 497 & 67.13 & 31.56 & 2.127 \\
\hline \multicolumn{5}{|c|}{ The treatment is TECHIMP } \\
\hline n. treat & n. contr. & ATT & Std. Err. & $\mathrm{T}$ \\
\hline 187 & 655 & 276.691 & 68.01 & 4.069 \\
\hline \multicolumn{5}{|c|}{ The treatment is BOTH } \\
\hline n. treat & n. contr. & ATT & Std. Err. & $\mathrm{T}$ \\
\hline \multicolumn{5}{|c|}{ The treatment is TECHIMP } \\
\hline n. treat & n. contr. & ATT & Std. Err. & $\mathrm{T}$ \\
\hline 187 & 655 & 0.054 & 0.060 & 0.910 \\
\hline \multicolumn{5}{|c|}{ The treatment is BOTH } \\
\hline n. treat & n. contr. & ATT & Std. Err. & $\mathrm{T}$ \\
\hline 178 & 1005 & 0.077 & 0.060 & 1.268 \\
\hline
\end{tabular}

Note: We bootstrap the standard error of the treatment effect and the number of bootstrap replications is 100 .

We conducted a treatment effect analysis to assess whether R\&D and/or technology spill-over influences the firm's profit, labor productivity, and TFP positively. We interpreted $\mathrm{R} \& \mathrm{D}$ and spill-over as treatments put an econometric matching, consider sufficient selection bias into account. The results show that the companies that took either or both of these measures outperformed the companies that received no treatment. When the companies' performance is measured by firm profit and labor productivity, the contribution of technology spill-over is more obvious, whereas if the firm's performance is reflected by TFP, then R\&D plays a more important role. Furthermore, the firms engaged in both of the development strategies simultaneously, so no strong positive effect could be identified. Finally, we concluded that further development of the Chinese economy concerning FDI imports may face various constraints. R\&D contributes more to a firm's long-term growth, although its positive effects may not become obvious at the beginning.

In addition, joint ventures seem to be successful in accepting spillovers from technology trade, which implies that 
they achieve superior performance if the firm performance is measured by profit and labor productivity. The positive link between R\&D and SOEs will eventually prove that SOEs achieve better firm performance if they are measured by TFP. The advantages of determining the S\&T department, patent application, and export performance creates the promising conditions that are necessary for potential spill-over effects and $R \& D$ improvement in the Chinese market.

Finally, our findings suggest firstly that advanced production technology and scientific management are both key sources for enterprise development. We should combine them closely and enhance the professional and technical personnel development, import high-level expertise, and promote the quality of human resources of SOEs and domestic non-SOEs. The empirical analysis results shows that joint ventures possess significant improvements, whether from technology importing or R\&D activities, either for short term or long term development. Therefore, at present, we need to appreciate the strong support of FDI spillover in the integration of various resources in order to enhance a firm's overall technical criterion. We must accept that the new concept of management and narrowing the gap between developed and developing countries are still key factors for both SOEs and domestic non-SOEs development. Secondly, we should concentrate on the second innovation based on the imports of technology. In order for the second innovation to succeed, the gradual formation of the firm's own technological and R\&D capabilities in the process of technology import are the significant issues. However, most of the Chinese firms today still face the same problem of stressing imports, but regrettably neglecting absorption. The R\&D inputs are still significantly low. To completely reverse the passive mode of "import-imitation-re-import-re-imitation", thereby shaking off dependence on foreign technology and truly achieving the sustainability of economic growth, both SOEs and domestic non-SOEs need to eliminate duplicating technology imports and ought to increase the technology digestion and absorption abilities, by intensifying R\&D investments, and establishing and perfecting a system of effective incentive mechanism of technical innovation. Thirdly, domestic firms ought to improve the current mechanism of scientific and technological activities and promote innovative activities and technological innovation efficiency. The present immediate objective is to overcome short-sighted development behaviour, maximize the enthusiasm of innovation, invest further R\&D funds in order to get technological superiority, and apply more competitive pressure on joint ventures. We would like to encourage a healthy mechanism on competence in technology between domestic firms and joint ventures in order to promote effective technological transfer and proliferation, consequently upgrading the technology altitude in the entire manufacturing industry in China.

\section{CONFLICT OF INTEREST}

The authors confirm that this article content has no conflict of interest.

\section{ACKNOWLEDGEMENTS}

The authors are grateful for the financial support provided by National Natural Science Foundation of China (NSFC) project 71473137 , China, 2014; NSFC project 71173122, China, 2012; academic leaders training project G12-XK03, Ningbo, China, 2012; young academic leaders training project pd2013072, Zhejiang, China, 2013; and the Institute of Regional economic and Social Development project QYJYNS1202, Ningbo University, China 2012.

\section{REFERENCES}

[1] R. C. Acharya, and W. Keller, "Technology Transfer Through Imports," National Bureau of Economic Research Working paper, 13086, 2007.

[2] J.D. Angrist, “ Estimating the labor market impact of volunta -ry military service using social security data" Econometrica, vol. 66, no. 2, pp. 249-288, 1998.

[3] B. J. Aitken, A. E. Harrison, "Do Domestic Firms Benefit from Foreign Direct Investment? Evidence from Venezuela", Amer -ican Economic Review, vol. 89, no. 3, pp. 605-618, 1999.

[4] B. Robert, "Notes on Growth Accounting" National Bur -eau of Economic Research Working Paper, vol. 6654, 1998.

[5] W. F. Baumol, "The Free Market Innovation Machine: Analyzing the Growth Miracle of Capitalism," Princeton Uniersity Press Princeton, 2000.

[6] R. Blundell, R. Griffith, J. Van Reenen, "Marke -t Share, Market Value and Innovation in a Panel of British Manuf -acturing Firms" Review of Economic Studies, vol. 66, no. 3, pp. 529-554, 1999.

[7] B. Eduardo, J. De Gregorio, and J. W. Lee, "Ho -w does Foreign Direct Investment Affect Economic Growth?," Jo -urnal of International Economics, vol. 45, pp. 115-135, 1998.

[8] C. Ricardo, and J. Adam, "How High are the Giant's Sh -oulders: An Empirical Assessment of Knowledge Spillovers and Creative Destruction in a Model of Economic Growth," National Bureau of Economic Research Working paper, vol. 4370, 1993.

[9] F. Caselli, and D. Wilson, "Importing Technology", National Bureau of Economic Research Working paper, vol. 9928, 2004.

[10] D. T. Coe, E. Helpman, "International R\&D Spillov -ers" European Economic Review, vol. 39, pp. 859-887, 1995.

[11] D. T. Coe, H. Elhanan, and H. Alexander, "North -South R\&D Spillovers", Economic Journal, vol. 107, no. 440, pp. 134-149, 1997.

[12] R.H. Dehejia, and S. Wahba, "Causal effects in nonexperimental st -udies: reevaluating the evaluation of training programs" Journal of the American Statistical Association, vol. 94, no. 448, pp. 1053$1062,1999$.

[13] M. K. Fung, "Technological Opportunity and Productiv -ity of R\&D Activities," Journal of Productivity Analysis, vol. 21, pp. 167181, 2004.

[14] M. Funk, "Trade and International R\&D Spillovers among OECD Countries" Southern Economic Journal, vol. 67, no. 3, pp. 725-736, 2001.

\author{
Received: June 10,2015 \\ Revised: July 29, 2015 \\ Accepted: August 15, 2015 \\ (C) Zhou et al.; Licensee Bentham Open.
}

This is an open access article licensed under the terms of the (https://creativecommons.org/licenses/by/4.0/legalcode), which permits unrestricted, noncommercial use, distribution and reproduction in any medium, provided the work is properly cited. 